UNITED STATES

DEPARTMENT OF THE INTERIOR

GEOLOGICAL SURVEY

A STUDY OF TRENDS IN DISSOLVED OXYGEN AND FECAL COLIFORM BACTERIA

AT NASQAN STATIONS

By Richard A. Smith and Richard B. Alexander

Open-File Report 82-1019 
Abstract- 1

Introduction and methods 1

Results and discussion 2

References- 5

\section{ILLUSTRATIONS}

Figure 1. Results of the Seasonal Kendall trend test applied to flow-adjusted measurements of dissolved oxygen concentration at NASQAN stations, October 1974 through

Figure 2. Results of the Seasonal Kendall trend test applied to flow-adjusted measurements of fecal coliform bacteria populations at NASQAN stations, October 1974 through October 1981

Figure 3. Results of the Seasonal Kendall trend test applied to flow-adjusted measurements of dissolved oxygen deficit at NASQAN stations, October 1974 through October 1981 


\title{
A STUDY OF TRENDS IN DISSOLVED OXYGEN AND FECAL COLIFORM BACTERIA AT NASQAN STATIONS
}

By Richard A. Smith and Richard B. Alexander

\begin{abstract}
Most stations in the U.S. Geological Survey's National Stream Quality Accounting Network show no significant trend in either dissolved oxygen concentration or fecal collform bacteria population for the period October 1974. through October 1981. Of the stations which do show trends, however, most show improved water quality: thirty-one of a total of 276 stations show rising dissolved oxygen concentrations, while only 17 show decreasing concentrations. Decreases in fecal coliform populations have occurred at 21 stations while increases have occurred at only 12 stations.

Approximately half of the stations showing improving trends in dissolved oxygen and fecal coliform bacteria are in the Missouri-Mississippi-Ohio River system. Decreases in dissolved oxygen have occurred at scattered locations in the Western and South-Central States. Rising bacterial populations occur most frequently in the Eastern and Central States

Trends in dissolved oxygen concentration resulting from temperature changes occurring during the study period can be separated from trends caused by chemical or biological processes by analyzing computed values of dissolved oxygen deficit. About half of the observed trends in dissolved oxygen appear to be the result of changes in water temperature.
\end{abstract}

\section{INTRODUCTION AND METHODS}

This report presents results of the Seasonal Kendall trend procedure (Hirsch and others, 1982) applied to measurements of dissolved oxygen (DO) concentration and fecal coliform bacteria populations at stations in the U.S. Geological Survey's National Stream Quality Accounting Network (NASQAN) for the period October 1974 through October 1981. The Seasonal Kendall procedure was designed for analysis of time trends in seasonally varying waterquality data from fixed, regularly-sampled monitoring sites such as those which comprise the NASQAN network. In addition to a test for trend, the statistical procedure includes an estimate of the median rate of change of quality over the sampling period (trend slope) and a method for flow-adjusting the data to correct for effects of changing stream flow on trend in the waterquality record.1/ Trend is defined here simply as monotonic change with time, occurring either as an abrupt or gradual change in water quality.

1/ Flow adjustment of fecal coliform bacteria measurements required modification of the Seasonal Kendall procedure to include log transformations of these data ( $R$. M. Hirsch, personal communication, 1982). 
A previous report (Smith and others, 1982) describes in detail an application of the Seasonal Kendall procedure to total phosphorus records at NASQAN stations.

\section{RESULTS AND DISCUSSION}

Figures 1 and 2 are maps depicting the results of flow-adjusted trend tests applied to NASQAN records for DO and fecal coliform bacteria, respectively. Triangles indicate the location of stations showing statistically significant ( $p<0.05)$ trends; the triangles point in the direction of change in flowadjusted concentration. The size of a triangle (small, medium, large) indicates the steepness of the trend slope or rate of change of quality. Shaded circles indicate the location of stations with no significant trend, either up or down, in the water-quality variable.

Most stations show no significant trend in either DO or fecal coliform bacteria for the period studied. Of the stations which do show trend, however, most show changes in the direction of improving water quality: thirty-one, of a total 276 stations, show rising DO concentrations, while only 17 show decreasing concentrations. Geographically speaking, increases in DO concentration have tended to occur at sites in Eastern and Central States, including a number of stations in the Ohio, Missouri, and Mississippi River basins. Decreases in Do concentration have occurred at scattered locations in Western and South-Central States, notably Oklahoma and Texas.

The observed trends indicating improving DO concentration may or may not be related to efforts of the past decade to control oxygen-demanding substances in water, including both point and non-point sources of those substances. In the absence of detailed information on changes in specific sources of organic pollution, it is impossible to be conclusive about the causes of trends in DO concentration at NASQAN stations, which are located on major U.S. rivers, typically draining areas of thousands of square miles. Future planned analysis of these data may shed further light on the causes of the observed trends.

Nevertheless, it is possible to proceed a further step towards separating man-induced changes in dissolved oxygen concentration from possible natural causes of the DO trends reported here. "Wet-year" versus "dry-year" effects are at least largely corrected for in figure 1 through flow adjustment, as referred above. But another important exogenous variable potentially affecting Do trends is temperature through its inverse relationship to the saturation level of dissolved oxygen. In the absence of other effects on DO, trends in water temperature (climatically induced or otherwise) would be expected to result in trends of the opposite direction in DO concentration. This effect can be corrected for by applying the trend testing procedures to values of DO "deficit" (calculated as saturation concentration minus observed concentration) based on water-temperature data collected at the time of DO sampling. 


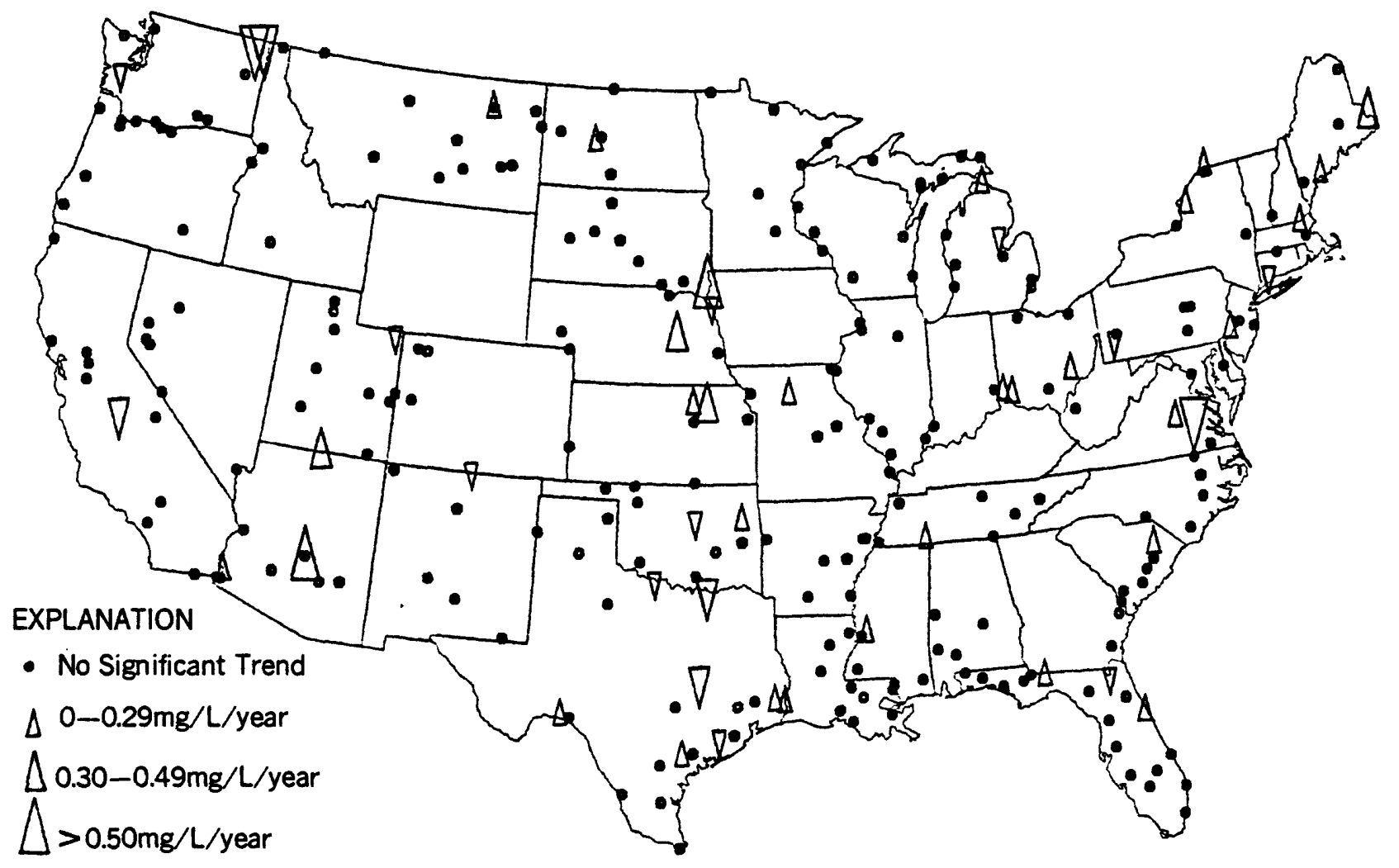

Figure 1.-- Results of the Seasonal Kendall trend test applied to flow-adjusted measurements of dissolved oxygen concentration at NASQAN stations for the period October 1974 through October 1981. Triangles point in the direction of satistically significant $(p<0.05)$ trend. 


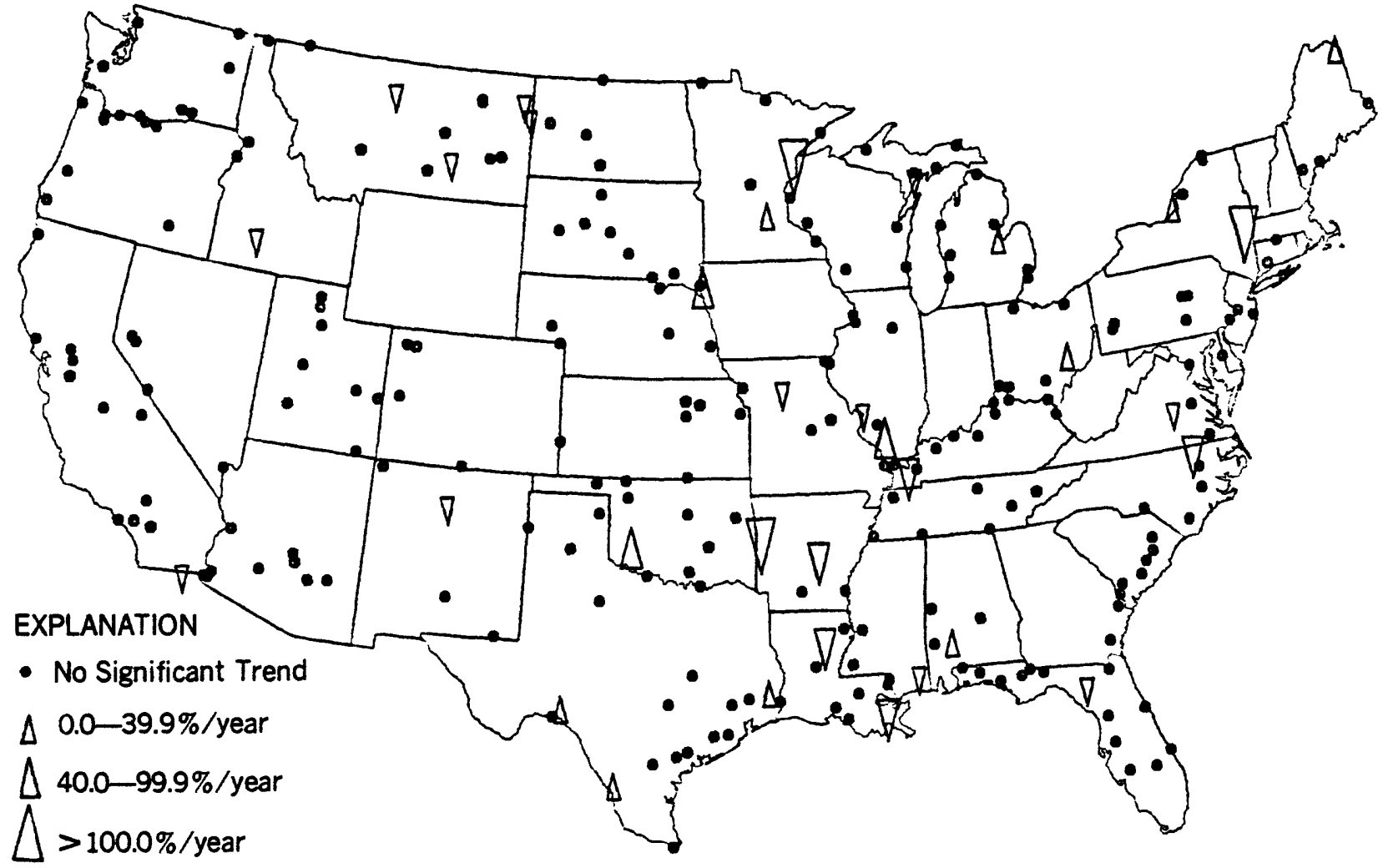

Figure 2.--Results of the Seasonal Kendall trend test applied to flowadjusted measurements of fecal coliform bacteria populations at NASQAN stations for the period October 1974 through October 1981. Triangles point in the direction of statistically significant $(p<0.05)$ trend. 
The results of these tests are given in figure 3. Trends in Do deficit would be expected to result only from a change in the chemical or biological processes which add or remove oxygen from the water such as photosynthesis or organic decomposition. Approximately half of the stations showing trends in DO concentration in figure 1 ( 15 up trends and 7 down trends) show trends in Do deficit of the opposite direction in figure 3. The remaining half of the stations showing trends in DO concentration do not show significant opposing trends in DO deficit and thus would appear to represent situations where changes in temperature rather than changes in pollution loads are the cause of observed DO changes. Finally, certain stations showing trends in Do deficit in figure 3 do not show trends in DO concentration and apparently represent sites where there have been changes in pollution loads that are obscured in figure 1 by temperature changes.

Fecal coliform bacteria may originate in runoff from agricultural lands as well as discharges from populated areas, and both types of sources have been subject to pollution control efforts of the past several years. The majority of trends in fecal coliform bacteria (fig. 2) are in the direction of improving quality ( 21 down trends versus 12 uptrends). Stations showing declines in bacterial populations occur at widely-scattered locations, with about half occurring in the Missouri and Mississippi basins. Rising bacterial populations occur most frequently at stations in Eastern and Central States.

Again, it is impossible on the basis of presently available data to be conclusive about the causes of trends in either direction because of the many sources of fecal colfform bacteria in large rivers included in the NASQAN program.

\section{REFERENCES}

Hirsch, R. M., Slack, J. R., Smith, R. A., 1982, Techniques of trend analysis for monthly water quality data: Water Resources Research, v. 18 , no. 1 , p. 107-121

Smith, R. A.. Hirsch, R. M., and Slack, J. R., 1982, A study of trends in total phosphorus measurements at NASQAN stations: U.S. Geological Survey Water-Supply Paper 2190, 34 p. 


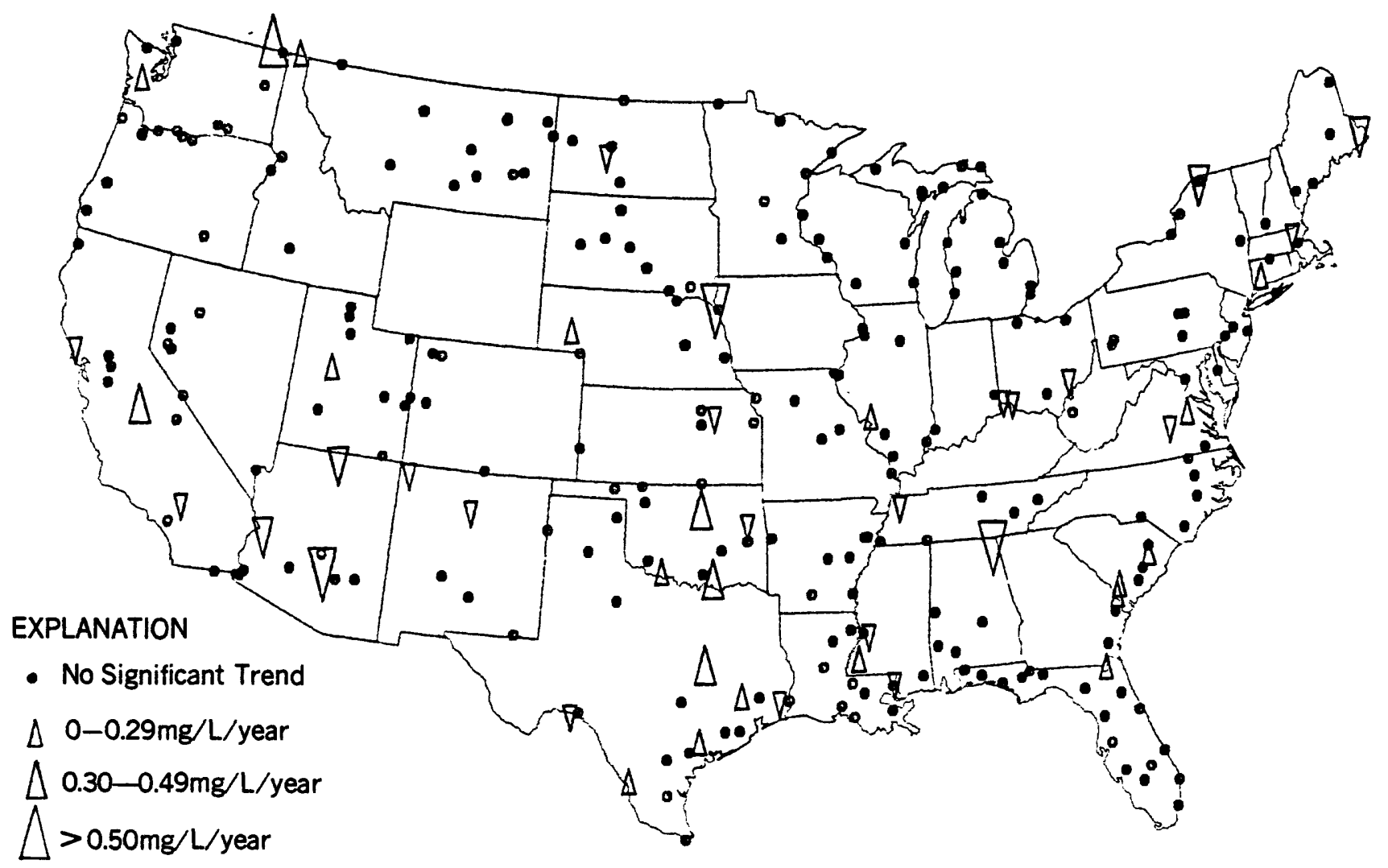

Figure 3.--Results of the Seasonal Kendall trend test applied to flow-adjusted measurements of dissolved oxygen deficit at NASQAN stations for the period October 1974 through October 1981. Triangles point in the direction of statistically significant $(p<0.05)$ trend. 